\title{
Romances judeoespañoles de Gibraltar
}

\author{
Oro ANAHORY-LIBROWICZ \\ Université du Québec, Montréal \\ A Flora Ohana de Roublev, gran dama sefardí, \\ que me deleitó con el cante de estos y otros romances
}

Esta colección de romances * creemos que presenta un interés especial, no tanto por la novedad de los textos recogidos como por su origen geográfico, ya que provienen de la comunidad sefardí de Gibraltar. La falta casi absoluta de documentación gibraltareña en las colecciones de romances publicadas hasta la fecha nos parece que otorga a este pequeño acopio un interés muy particular.

Mi informante, Flora Ohana de Roublev, nació en Casablanca y tenía 68 años cuando realicé mi encuesta en 1973. Su único lazo con la tradición española lo constituyó su madre, oriunda de Gibraltar, quien le enseñó la lengua de sus antepasados y le transmitió la presente muestra de esa joya de la literatura oral judeoespañola que son los romances. Por el lado

- Redacté el presente artículo en 1973. En una revisión bastante posterior titulé y ordené los romances según el Catálogo-índice de S. G. ARmistead et al. (vid. infra); pero estimando que el mayor interés del artículo estriba en la presentación de los textos, me abstuve de cualquier otro cambio o adición que me obligara a refundir totalmente los comentarios. Por ello no he tenido en cuenta mi propio libro Florilegio de romances sefardíes de la diáspora (Una colección malagueña) (Madrid: CSMP, 1980 [1981]), cuyos textos 10,11, 12, 13, $14,20,23$ y 27 corresponden respectivamente a los $5,3,4,6,8,9,14$ y 11 de Gibraltar; ni mi edición en colaboración con S. G. ARMistead y J. H. Silverman, Romances judeo-españoles de Tánger recogidos por Zarita Nahón (Madrid: CSMP, 1977), cuyos números $14,21,24,25,26,32,38,42$ y 53 representan los $2,5,3,4,6,8,10,9$ y 13 de nuestro repertorio gibraltareño: a sus estudios y comentarios remito para complemento de lo aquí expuesto. 
paterno no hubo transmisión de cultura tradicional, puesto que el padre de mi informante era de Casablanca y hablaba sólo francés.

La existencia de una comunidad sefardí en Gibraltar es un hecho relativamente reciente. Sus miembros son descendientes de judíos tangerinos y tetuaníes, de modo que la tradición romancística sefardí de Gibraltar tiene innegables lazos con la marroquí. Pero a la vez hemos de considerar que la posición geográfica de Gibraltar, al extremo sur de la Península, deja expuesta esa comunidad a una influencia andaluza aún más fuerte que la que se ha hecho sentir en el romancero de todas las comunidades del norte de Marruecos.

En el caso de mi informante intervienen otros factores que aumentan notablemente la complejidad de su repertorio. En éste las dos tradiciones -marroquí y peninsular-se encuentran concretamente confirmadas por dos hechos: la estancia de la Sra. de Roublev en Tánger en 1937-38 y 1939-41, y el contacto de su madre con señoras españolas de Ceuta, de quienes aprendió no pocos romances y otras canciones tradicionales que los ceutíes llaman mañanitas (núms. 4, 14, 15 y seguramente 8). Después de vivir en Tánger, la Sra. de Roublev se estableció en Nueva York en 1942, donde -según sus palabras- no enriqueció su caudal de romances.

El repertorio romancístico de nuestra informante, única muestra conocida hasta la fecha del romancero judeoespañol de Gibraltar, integra romances de las siguientes categorías, según el conocido «Catálogo» de Menéndez Pidal ${ }^{1}: a$ ) históricos (núm. 1),e) de asunto clásico (núm. 2), g) de amor fiel (núms. 3-6), h) de amor desgraciado (núm. 7), $i$ ) de esposa desdichada (núm. 8), $k$ ) de mujeres matadoras (núm. 10), $l$ ) de raptos y forzadores (núms. 9 y 11) y $\tilde{n}$ ) de asuntos varios (núm. 12), amén de otros tres (núms. 13-15) que no constan en dicho «Catálogo» 2 .

1 R. MenÉndez Pidal, «Catálogo del romancero judío-español», Cultura Española 4 (1906) págs. 1045-1077, y 5 (1907) págs. 161-199 [abrev. MP]; reimpreso, con abreviación de algunos textos y comentarios, en Los romances de América y otros estudios (Madrid: "Austral» 55, $6^{\mathrm{a}}$ edic. 1958) págs. 114-179.

2 Nótese que la distribución en categorías y en consecuencia la numeración de los romances han variado tras la nueva catalogación de S. G. ARMisTEAD et al., El Romancero judeo-español en el Archivo Menéndez Pidal (Catálogo-índice de romances y canciones), 3 vols. (Madrid: CSMP, 1978) [abrev. CMP]: ambas 


\section{Abenámar (í-a) (MP $10 /$ CMP C.5)}

- Abenámar, Abenámar, moro de la morería,

2 el día que tú naciste grandes señales había, estaba la mar en calma, la luna estaba prendida:

4 moro que en tal signo nace no debe decir mentira. -No vos la diré, señor, que eso es grande villanía,

6 que cuando niño y muchacho mi madre me lo decía: que mentiras no diría aunque me cueste la vida;

8 por tanto pregunta, rey, que la verdá te diría. - ¿Qué castillos son aquellos, grandes son y relucían?

10 -El uno el Generalife, castillo de gran valía; el otro era la Alhambra, labrados a maravilla:

12 el moro que los labraba cien duros ganaba al día y el día que no trabaja otros tantos que perdía;

$14 \mathrm{y}$ el otro Torre Bermeja, labrados a maravilla.

$1 a$ «Abenamar A.»; $5 b$ «qu'eso»; $12 b$ «ganab'al». Tras $14 a$ inicia «cas-» (cfr. 10b), titubea y acaba repitiendo $11 \mathrm{~b}$; al final comenta: «Hay más, pero no me acuerdo».

Es el único romance histórico de nuestro repertorio ${ }^{3}$. Como muestra Paul Bénichou en su minucioso estudio ${ }^{4}$, es sin duda uno de los romances viejos más elaborados y logrados poéticamente.

Sabemos que las versiones de Abenámar que se conocen en Marruecos suelen ser aprendidas de libros de texto. Aunque mi informante me anunció con cierta solemnidad que iba a cantar «un romance del siglo XV», es obvio que su versión no se ha venido transmitiendo por vía oral desde entonces, sino que, como la mayoría de las marroquíes, procede de versiones antiguas impresas en los siglos XVI y siguientes. En efecto, corresponde fielmente al texto publicado en 1595 por Ginés

\footnotetext{
numeraciones -la de MP y la del CMP- las indicamos en cabecera de cada texto tras el título y la asonancia. Cada comentario lo iniciamos con unas notas textuales y de incidencias en la recolección del texto. Para las colecciones de textos a las que aludimos abreviadamente véase la Bibliografía al final.

Véase E. BUCETA, «Un dato sobre la historicidad del romance de "Abenámar" ", Revista de Filología Española 6 (1919) págs. 57-59. Véase también R. Menéndez Pidal, «Los orígenes del romancero» (sobre R. Foulché-DelbosC Essai sur les origines du Romancero [1912]), Revista de Libros 2:7 (en. 1914) págs. 3-14: págs. 9-13 (reproducido en Los romances de América págs. 88-103: págs. 96-102).

${ }^{4}$ Creación págs. 61-92.
} 
Pérez de Hita en sus Guerras civiles de Granada ${ }^{5}$, con la omisión de la declaración del rey don Juan a Granada y de la contestación de la ciudad personificada (vid. infra) y la diferencia de que en la enumeración de los monumentos olvida la evocación de los Alijares y comete el error de identificar el Generalife como castillo en vez de como jardín.

Aun siendo nuestra versión obviamente de origen escrito, parece interesante señalar la coincidencia de las dos tradiciones -gibraltareña y marroquí- en la elección de Abenámar entre los numerosos poemas impresos en libros de texto o en colecciones divulgadas de romances. Además, se puede quizás observar en la versión gibraltareña un incipiente proceso de elaboración oral en algunas variantes de interés.

La «luna crecida», como explica Bénichou, figura en otros romances como presagio fatal; no en Espinelo, donde indica en la hora de su nacimiento la excelencia del protagonista; así «Un mismo esquema textual y estilístico ha sido utilizado en Abenámar y Espinelo» ${ }^{6}$. En nuestra versión, sin embargo, la utilización de este esquema no se hace automáticamente, pues mi informante aporta la variante estilística "prendida» en vez de «crecida» (v. 3): ambos adjetivos sugieren claridad y plenitud; pero la mera sustitución de una palabra por otra, en un lugar común, le concede un nuevo valor poético a una evocación algo desgastada. En segundo lugar, en nuestra versión se elimina el detalle de la madre cristiana, poco acertado según Bénichou, pues disminuye la tensión de la confrontación entre el moro y el cristiano al hacer del primero un moro con sangre cristiana ${ }^{7}$ : nuestra versión acentúa, pues, la intensidad del diálogo entre los dos personajes. La sustitución de «doblas» por «duros» (v. 12) refleja un proceso tradicional muy frecuente, que consiste en reemplazar elementos desconocidos por otros que forman parte del medio ambiente del recitador.

5 Sobre la reproducción de esta versión en colecciones modernas véase BÉnICHOU Creación pág. 69 nota 10. Por otra parte, sí parece ser que circulaban en Marruecos versiones de Abenámar «auténticas» y de tradición directa; para más datos véase $C M P$ C.5 y núms. $8 B-8 C$ de la "Antología» (vol. III pág. 16).

${ }^{6}$ Creación págs. 82-83. Sobre el romance geminado en Marruecos de Abenámar + Espinelo (CMP C.5 + G.1) véase ahora mi artículo "Creación poética en tres versiones sefardíes del romance de Espinelo», La Corónica 10:1 (otoño 1981) págs. 59-64.

7 Creación pág. 86. 
Es digna de señalarse là omisión, muy poco feliz, de la declaración final del rey don Juan cuando se dirige a Granada con requiebros de amante, así como de la respuesta de la ciudad. Este final trunco oscurece el sentido del diálogo entre el moro y el cristiano. ¿Consistiría la única finalidad de la pregunta del rey -«Qué castillos son aquellos ...» (v. 9)- en el goce poético de oír nombrar los monumentos de Granada? En tal caso, el poema queda amputado del contexto histórico en que se debe desarrollar.

\section{Virgilios (é) (MP 46 / CMP F.8)}

Preso llevan al Velĝico y el rey le mandó a prender

2 por una traición que ha hecho $\mathrm{y}$ en los palacios del re por forzar a una doncella, la cual se llama Isabel;

4 hija era del obispo, sobrina del señor re.

Un día fue el rey a misa, se encontró esa mujer

6 toda ella vestida de luto, ella y sus damas también.

Preguntó el rey a su alcalde que quién era esa mujer.

8 -Vuestra sobrina, señor re, vuestra sobrina Isabel.

- ¿Por quién va vestida de luto ella y sus damas también?

10 -Por Velǵico, mi señor, que en vuestra prisión tenés.

- Aína, mis caballeros, poned la mesa a comer;

12 mientras las mesas se aprontan al Velĝico iré yo a ver.

-En buena hora estés, Velǵico. -Bien vengáis, mi señor re.

$14-¿$ Qué hace tiempo, Velĝico, que en mis presiones yacés?

- Siete años eran, siete, cuando en la prisión entré;

16 siete años eran, siete, siete años y más un mes.

- ¿Qué darías tú, Velĝico, por volver con Isabel?

18 -Los años de mis presiones los doblaría otra vez; cuando entré yo en tus prisiones yo me empecé a embarbe-

$20 \mathrm{y}$ ahora, por mis pecados, yo me empecé a encanecer.

-No permita Dios del cielo ni lo quiera yo también;

22 aína, mis caballeros, sáquenle de prisión ${ }^{-}$

Otro día por la mañana las ricas bodas se armó.

$11 a, 22 a$ «Aina»; $13 a$ «Es b. h.»; 14a entiéndase «Qué tiempo hace, V.»; $14 b$ «yacés».

De este romance, el más antiguo de los quince del ciclo virgiliano que enumera Menéndez Pidal en su artículo «Un episo- 
dio de la fama de Virgilio en España» ${ }^{8}$, se conocen versiones peninsulares, orientales y marroquíes ${ }^{9}$. La nuestra es sin duda sefardí y antigua, pues excepto algunas variantes menores, se parece mucho a las de Alvar, Bénichou y Larrea: nombre del protagonista (Velgico o Velǵico, passim), rastros de léxico arcaico (aina, vs. 11, 22; se aprontan, v. 12) y el propio contenido.

Nuestro texto incorpora dos breves contaminaciones al final: el v. 21 proviene de La vuelta del marido (é) (MP 59 / CMP I.2) y el v. 22 refleja uno de los varios desenlaces de Sancho y Urraca (MP 4 / CMP A.4-5); huelga decir que el v. 23 es una fórmula migratoria que sirve de desenlace en un sinfín de romances ${ }^{10}$.

Es interesante observar que, contrariamente a la mayoría de los textos de la presente colección, esta versión apenas presenta tendencia a la brevedad. El que tengamos sólo un ejemplo gibraltareño no nos permite determinar si éste es un texto de Tetuán o Tánger que pasó en fecha reciente a Gibraltar, o si es tal vez una muestra «autóctona» excepcionalmente bien conservada.

\section{La vuelta del marido (é) (MP 59 / CMP I.2)}

-Escuchís, señor soldado, si de las guerras venés,

2 si ha visto a mi marido en las guerras del francés.

-Su marido está muerto, muerto está, que yo lo sé,

4 y en su testamento dice que me case con usted. -Siete años he esperado y otros siete esperaré,

6 si a los catorce no viene a monja me meteré; de las tres hijas que tengo ¿dónde las colocaré?:

8 una a casa doña Juana y otra a casa doña Inés y la más chica de ellas conmigo la dejaré

10 para que me lave y planche $y$ me haga de comer.

5 «S. a. h'esperado / y o. siet'esperaré»; 8 «un'a c. ... / y otr'a c. ...».

${ }^{8}$ Studi Medievali 5 (1932) págs. 332-341: págs. 332-333.

9 BÉNICHOU Romancero 25 (págs. 99-102); LARREA Romances 51-53; otras referencias bibliográficas en BÉNICHOU pág. 99; véase el estudio de ALVAR «Los romances», con tres textos.

${ }^{10}$ Cfr., por ejemplo, BénıCHOu Romancero 2.33 (pág. 69), 3.31 (pág. 77), 33.23 (pág. 147) y 11.26 (pág. 175). 
Este romance, cuyos orígenes exploró Bénichou ${ }^{11}$, es popularísimo en Marrue $\cos ^{12}$ y difundidísimo en España y América. Nuestra versión se caracteriza por su brevedad (10 versos, mientras que la de Attias tiene 16 y las de Ortega y Bénichou Romancero 19). Quedan eliminadas las señas destinadas a identificar al marido, que como observa Bénichou, constituyen un motivo folclórico universal. Faltan también los versos «No permita Dios del cielo, / ni mi madre santa Inés» (versión peninsular de Durán 318) y «monja como santa Clara, / monja como doña Inés» (Bénichou); mientras que el verso «la una en santa Clara, / la otra en doña Inés» de Bénichou está aquí (v. 8) totalmente secularizado al haberse reemplazado «santa» por «doña»; de modo que queda una única alusión al mundo cristiano: «a monja yo me meteré» (v. 6). En el final trunco no se alude al reconocimiento de los esposos, que es el tema central del romance.

\section{El conde Niño (á) (MP 55 / CMP J.1)}

Se paseaba conde Olivo mañanita de San Juan

2 a dar agua a su caballo a la orillita del mar; mientras su caballo bebe, él cantaba este cantar;

4 las aves que iban volando se paraban a escuchar. Desde la torre más alta la reina le oyó cantar:

6 -Mira, hija, cómo canta la sirenita del mar.

-No es la sirenita, madre, que ésa tiene otro cantar:

8 es la voz de conde Olivo que por mí llorando está.

-Si es la voz del conde Olivo, yo lo mandaré a matar,

10 que para casar contigo le falta la sangre real.

-No lo mande a matar, madre, no lo mande usté a matar,

12 que si mata a conde Olivo a mí la muerte me da.Mandaría a sus criados al conde Olivo matar:

14 que lo saquen a lanzadas y echen su cuerpo a la mar.

La niña, como es tan niña, no hace más que llorar.

16 El murió a la media noche, ella a los gallos cantar.

$12 a$ «q. si mat'a c. O.»; $13 a$ «Mandarí'a»; $16 b$ «ell'a los g. c.». Tras cada verso par se repite su segundo hemistiquio -salvo $14 b-$ y luego el verso entero ( $8 a$ «Olino»), precedida por “y" la primera repetición de $16 b$.

11 Romancero 15 (págs. 227-234).

12 Otras versiones marroquies: Larrea Romances 74-77; MP 59; MZ. Ruiz 68; ORTEGA págs. 212-213; seguramente es también de origen marroquí la versión oriental publicada por Atrias (núm. 18). 
Este romance, popularísimo tanto en la tradición sefardí de Oriente y Occidente como en la peninsular e hispanoamericana, se nos presenta aquí en una versión trunca, de la que están ausentes las transformaciones maravillosas de los amantes y la venganza de éstos, detalle muy frecuente en las versiones orientales y peninsulares ${ }^{13}$. Según mi informante, se trata de una versión peninsular aprendida en Ceuta; las coincidencias con otras versiones marroquíes reflejan la notable influencia de semejantes textos peninsulares en la tradición sefardí norteafricana.

5. ¿Por qué no cantáis la bella? (é-a) (MP 57 / CMP J.4)

Una hija tiene el re, una hija regalada,

2 su padre por más valor un castillo le fraguara.

- ¿Por qué no cantas, la flor, por qué no cantas, la bella?

4 -Ni canto ni cantaré, que mi amor está en la guerra;

una carta escribiré de mi puño y de mi letra

6 que me traigan a mi amor sano, libre y sin cadenas; y si no me lo trajeran armaré una grande guerra

8 de navios por la mar, de hombres armados por tierra; si no hubiera bandera mis lindas trenzas pusiera

10 y si no tuviera remos mis blancos brazos yo diera; si no hubiera capitán me subiera a la bandera

12 para que la gente diga: "Viva, viva esa doncella que por salvar a su amor se echó ella a la tormenta».

$1 a$ «tien'el re»; $11 b$ «me subier'a la b.»; $13 b$ «se e. ell'a la t.». Se interrumpe y titubea en $9 a$ y $13 b$.

Este romance antiguo, del que se conocen textos peninsulares $^{14}$, americanos ${ }^{15}$, marroquíes ${ }^{16}$ y orientales ${ }^{17}$, aparece aquí

13 Véanse detallada bibliografía y amplio comentario sobre el romance en ARmistead-Silverman Yoná 12 (págs. 152-173). Otras versiones marroquíes: Alvar "Cinco romances» 2; BÉnichou Romancero 28 (págs. 123-128); LARREA Romances 67-69; MP 55; Mz. Ruiz 66.

14 Véase el artículo de P. BÉNıchou, «La Belle qui ne saurait chanter: Notes sur un motif de poésie populaire», Revue de Littérature Comparée 28 (1954) págs. 257-281, y en particular la reproducción de una versión aragonesa recogida por Menéndez Pidal p. 259. Véase también R. Menéndez Pidal, Romancero hispánico vol. II págs. 218-219.

15 Versión venezolana de L. F. Ramón y Rivera e I. ARETz, Folklore tachirense (Caracas 1961-1963) I:2 pág. 636.

16 Alvar Cantos 56 (págs. 333-334); BÉnichou Romancero 10 (págs. 169-174); LARREA Romances 71-73; MP 57; MZ. RuIz 67.

17 AtTias 46; y una versión de Bosnia publicada en Spomenica ... (1566-1966) (Sarajevo 1966) y reproducida en ARmiSTEAd-Silverman Bosnia págs. 6-7. 
en versión algo abreviada. De los versos que corrientemente encabezan el romance (varían entre dos y seis), sólo dos figuran en nuestra versión; según mi informante, no era ése el comienzo original del poema, y en efecto, son versos asonantados en $a$ - $a$ (el resto tiene asonancia $e ́-a$ ), que bien podrían pertenecer a La princesa y el segador (MP 108 / CMP Q.5). Faltan también los versos en que se presenta a la dama peinando sus cabellos o bordando un camisón, motivos tradicionales ambos de uso frecuente en el romancero; en consecuencia, la pregunta del caballero surge de manera aún más arbitraria que en las otras versiones, donde -como explica Bénichou- los motivos se encadenan hasta llegar a la pregunta crucial: « $¿$ Por qué no cantáis, la bella?».

Viene luego el monólogo de la heroína, que desarrolla el motivo folclórico de la mujer guerrera. Nuestro texto incorpora la imagen tradicional de los brazos remos (v. 10); otra, del todo aberrante, de las trenzas - bandera (v. 9) es sin duda una contaminación proveniente del v. 11, pues la lectura más frecuente en las versiones marroquíes es trenzas velas.

\section{Diego León (á-a) (MP 63 / CMP J.5)}

En la ciudad de Toledo y en la ciudad de Granada

2 allí se cría un mancebo que Diego León se llamaba. Era bajito de cuerpo, morenito de su cara,

4 delgadito de cintura, mozo criado entre damas.

De una tal se enamoró, de una muy linda y muy guapa,

6 se miran por los balcones, se miran por las ventanas y el día que no se ven no les aprovecha nada:

8 no les aprovecha el pan ni les aprovecha el agua ni les aprovecha el dinero con que León trabajaba.

10 Un día fue a ve a su padre a ver lo que el rey pensaba: -Hija, León te ha pedido, váyase en hora mala,

12 que los bienes de este mundo Dios los daba y los quitara. -Padre, casaime con él aunque nunca me deis nada.-

14 Mandaba cuatro valientes para que a León le mataran. Otro día a la mañana León en la plaza estaba.

$5 a$ «s'enamoró»; $11 b$ «váyas'en»; $15 a$ «Otro dí'a la m.». Se interrumpe y titubea en $11 b, 12 a, 14 a$ y $15 a$. 
El romance de Diego León, uno de los más difundidos entre los sefardíes de Marruecos ${ }^{18}$, presenta características de los romances novelescos tardíos, que relatan minuciosamente las aventuras amorosas de los protagonistas; pero Armistead y Silverman han demostrado que se trata de un texto antiguo, derivado de una jácara del siglo XVI ${ }^{19}$.

Nuestra versión, muy incompleta, está bastante estropeada. Desde el v. $10 \mathrm{mi}$ informante empezó a titubear y sin mi ayuda no hubiera podido siquiera llegar hasta el v. 15. Si nos atenemos a semejante testimonio, el romance no sería quizás de los más difundidos en Gibraltar; será sin embargo aventurado juzgar sobre la popularidad o rareza del tema sin haberse realizado otras calas en la tradición gibraltareña.

\section{La novia del conde de Alba (í-a) (MP 65 / CMP K.4)}

Tristès nuevas, tristes nuevas se decían por Sevilla:

2 que se casa el conde de Alba con dama de gran valía. Se paseaba por su cuarto donde lloraba y gemía,

4 sus blancas manos retuerce y sus anillos torcía; vio venir al conde de Alba con toda su compañía.

6 - Conde de Alba, conde de Alba, conde de Alba de mi vida, que me han dicho que te casas con dama de gran valía.

8 -Quien te lo vino a decir que mentiras no decía: mis bodas serán mañana y a convidarte venía.$10 \mathrm{Al}$ oír estas palabras cayó de punta la niña. - ¡Ay, qué malos son amores!, pero yo no lo sabía 12 que se pone el corazón lo de abajo para arriba.

8 No puede excluirse puntuación interrogativa; $12 b$ "pár'arriba».

Mi informante asegura que lo aprendió de un disco, añadiendo que es un romance que no cantan los sefardíes. No es cierta sin embargo semejante afirmación: se trata de un romance rarí-

${ }^{18}$ Conocemos las siguientes versiones publicadas: Alvar Poesía 63.A; BÉNichou Romancero 20 (págs. 269-271); GuASTAVIno 5; LARREa Romances 82-83 y 84 (vs. 1-77); MP 63; MZ. RuIz 70.

19 «Sobre el romance "En vna Villa pequeña" (Xácaras y romances varios, Málaga, 1668)», Sefarad 31 (1971) págs. 184-186. 
simo, documentado hasta ahora entre los sefardíes sólo en una versión tangerina del Archivo Menéndez Pidal ${ }^{20}$.

La tonalidad melódica de nuestro texto recuerda bastante a la de las endechas: la asonancia en $i$-a da de por sí una impresión plañidera; y el intenso drama interior del amor desafortunado está concentrado en unos pocos pero significativos detalles: lloraba, gemia, retuerce, torcia (vs. 3-4), cuatro verbos que en la relativa sobriedad del relato cobran una intensidad aún mayor. En particular el detalle de retorcerse manos y anillos es comparable, a mi parecer, a los gestos rituales que acompañan los duelos, como mesarse el cabello o echarse ceniza; tal detalle resulta ciertamente menos espectacular pero también no menos conmovedor: al torcer sus «blancas manos» (v. 4 , nótese que es el único rasgo físico en el texto) la protagonista, a quien sólo se nombra como «la niña», destruye o descompone el orden natural, proceso que culmina en el desmayo («cayó de punta la niña», v. 10) y en la angustiosa imagen final del corazón volcado («lo de abajo para arriba», v. 12); ésta se expresa de modo más congojoso en la versión de Menéndez Pidal, donde los «doctores», llamados «a ver de qué mal moría», le abren el pecho y «le encuentran el corazón / lo que era de abajo arriba» (vs. 9 y 11) ${ }^{21}$.

\section{La mujer engañada (i-a) (MP 74 / CMP L.13)}

Me casó mi madre chiquita y bonita

2 con un buen muchacho que yo no quería.

La noche de novia entraba y salía;

4 le seguí los pasos por ver dónde iba, yo le vide entrar en casa de su amiga;

6 entre puerta y puerta un cantar decía:

-Tú eres mi alma, tú eres mi vida

8 y la otra mujer palos y mala vida.-

Él escancia el vino, ella lo bebía.

${ }^{20}$ MP 65 / CMP K.4/1 y edición del texto en núm. 26 de la «Antología» (vol. III pág. 34). Para una variante peninsular del mismo romance véase M. MENÉNDEZ PELAyo, Antología de poetas líricos castellanos, vol. IX = Ed. Nac. vol. XXV (Santander 1945) pág. 189 (reproduce la versión asturiana publicada por Juan Menéndez Pidal en 1885).

${ }^{21}$ Para un más detallado estudio del texto véase mi nota «Una variante gibraltareña de La novia del Conde de Alba», La Corónica 13:2 (primavera 1985) págs. 255-257. 
10 Me fui a mi casa triste y afligida;

a la media noche él que ya volvía.

12 -Ábreme, mi alma, ábreme, mi vida,

que vengo cansado de rondar la vida.

14 -Tú vienes cansado casa de querida.

Repite cada hemistiquio, precedidos de "ayayay» los segundos («yayayay» en $4 b$ ) con las variantes: $5 a$ Quizás «yo le vi de e.», $5 b$ om. «en», $6 a$ precede. «y», $8 a$ «y a la otra mujer».

Está documentado el romance en ambas tradiciones sefardíes ${ }^{22}$ y en la peninsular: en aquélla conserva el carácter antiguo, mientras que en ésta, modernizado, sirve de canción de corro infantil. Nuestra versión es de origen peninsular moderno, como lo atestigua el comienzo: «Me casó mi madre / chiquita y bonita // con un ser villano / que yo no quería», frente al inicio habitual en las judeomarroquíes antiguas: «Ese ser villano (o sevillano) / que no adormecía // cogió (o tomó) espada en mano / (y) fue a rondar la vía». La versión peninsular no sólo tiene una melodía diferente de las marroquíes «auténticas», sino que añade como estribillo la exclamación «ay, ay, ay» que lo adapta al ritmo de canción de corro. Falta en nuestra versión el característico verso "yo te compraré / sayas y mantillas», al que se contrapone el de «y a la otra mujer/palos y mala vida» (v. 8).

\section{Las bodas en París (í) (MP 95 / CMP M.14)}

Las ricas bodas se hicieron y en la ciudad de París

2 entre damas y señoras y entre caballeros mil;

la que llevaba la danza y era doña Beatriz.

4 Mirándola está ese conde y ese conde de París.

- ¿Qué miras tú allí, el conde; conde, qué miráis ahí?;

6 o mirabais a la danza o me mirabais a mí.

El marido tengo viejo, anda y vámonos de aquí;

8 los hijos tengo chiquitos, no se acordarán de mí.-

Al bajar las escaleras al marido vio subir.

${ }^{22}$ Versiones de Marruecos: BÉnICHou Romancero 7 (págs. 129-133); LARREA Romances 103-106; MP 74; Mz. RuIz 37; Mz. TORNER pág. 245 (núm. 145); ORTEGA págs. 221-222. 
$10-¿$ Qué llevas tú ahí, el conde; conde, qué lleváis ahí?

-Llevo yo a un pajecito que lo compré para mí.

12 -Llévalo por esta noche, mañana vuélvele aquí.

$6 a / b$ «mirabáis»; $10 a \ll Q$. lleváis tú».

Este romance antiguo, casi olvidado en la tradición peninsular, como señala Bénichou ${ }^{23}$, es en cambio conocido en la tradición sefardí, tanto de Oriente como del norte de África. En comparación con las versiones publicadas por Bénichou y Ortega y con otras dos tetuaníes aún inéditas que recogí en Madrid en 1971, esta de Gibraltar presenta como peculiaridad notable la supresión de algunos versos: los requiebros del conde a la dama, las alusiones a las hijas en la escuela, las señales previas a la aparición del marido y el reconocimiento por éste de la identidad del «paje».

Cabría quizá pensar que el romance, al circular entre los judíos de Gibraltar, siguiera un proceso de eliminación o reducción de los detalles a lo esencial, proceso bien conocido en la transmisión de poesía tradicional ${ }^{24}$; un ejemplo típico sería la falta de transición entre la atrevida proposición de la dama (vs. 7-8) y la aparición del marido (v. 9), que en las versiones arriba aludidas resulta menos repentina al estar en cierto modo «preparada» por detalles como «se la amató el candil» y «se la arrastró el chapí». Tal proceso de simplificación podría explicarse en este caso por el hecho de que la generalidad de los españoles de Gibraltar desconocían el romance, vivo sin embargo entre los sefardíes; el reducido número de éstos junto con la falta de popularidad del tema entre el resto de la población habrían dado lugar a un desarrollo autárquico que hiciera caer en el olvido pasajes del poema, sin favorecer en contrapartida el desarrollo de otros recursos de transmisión oral más creadores. Ahora bien, dado que sólo disponemos de un único texto gibraltareño, lo anterior no puede ser más que una hipótesis, que sólo podría confirmarse mediante el hallazgo de otros testimonios de la tradición de Gibraltar.

23 Véanse su versión y comentario en Romancero 5 (págs. 138-141). Otros textos marroquíes: Alvar Textos 359 (vs. 24ss); Larrea Romances 142-143; MP 95; Mz. Ruiz 78.A-C; Ortega págs. 214-215.

${ }^{24}$ Véase R. MenÉndez Pidal Romancero hispánico vol. I pág. 3. 


\section{La envenenadora (é-a) (MP $88 / C M P$ N.2)}

-Abridme, Cara de Rosa, abridme la puerta,

2 que de siempre fuistes mía, cuanto y más ahora.Abajó Cara de Rosa y le abrió la puerta,

4 tócanse mano con mano y vanse a la huerta. Debajo de un rosal verde pusieron la mesa;

6 ya comieron, ya bebieron, dormidos se quedan. Hacia allá a la medianoche Adelino se queja.

$7 a$ Inicia «Haci'all'a la madr-» pero se rectifica.

Se conocen relativamente pocos textos de este romance sefardí, cuyas versiones marroquíes publicadas no pasan de cuatro ${ }^{25}$; durante el verano de 1972 recogí en Caracas una versión tetuaní, aún inédita, más completa que el texto que ahora doy a conocer. Éste sólo representa un fragmento del romance y coincide puntualmente con el publicado en el «Catálogo», siendo difícil saber incluso si se transmitió por vía oral o si proviene de alguna fuente escrita. Podría ser éste el caso de mi informante; pero no creo que se pueda desechar la primera posibilidad, dados los estrechos lazos mantenidos por la tradición gibraltareña con la marroquí.

\section{Delgadina (á-a) (MP $99 / C M P$ P.2)}

Rey moro tenía tres hijas, todas tres como la plata

2 y la más chica de ellas Adelina se llamaba.

Un día estando en la mesa su padre la remiraba.

4 -Padre, ¿qué me mira usted? -Hija, no te veo nada;

me ha mandado la justicia que te encierre en una sala:

6 cuando pidas de comer, carne de perro salada; cuando pidas de beber, agua de la mar salada;

8 cuando pidas de dormir, el poyete la ventana; cuando pidas de tapar, las paredes de la sala.-

10 Se asomó a la primavera y vio a su hermano pasar. -Pronto, pronto, mis criados, traed un vaso de agua.-

12 Cuando llegan los criados la niña entregaba el alma.

$3 a$ «estando ' $\mathrm{n}$ "; $5 b$ "q. t'encierr'en». Repite cada hemistiquio -salvo $3 b, 5 b$ y $9 b$-con la variante $11 b$ «trae».

${ }^{25}$ MP 88; LARREA Romances 129-130; Mz. RuIz 75. 
El romance de Delgadina es muy popular en España y América. Bénichou observa ${ }^{26}$ que las versiones que se conocen en Marruecos habrían penetrado en época relativamente tardía. Nuestra versión, radicalmente abreviada, ha de ser de origen peninsular.

12. El sueño de la hija (í-a) (MP 129 / CMP S.6)

Y este rey de Francia tres hijas tenía,

2 la una lavaba, la otra cosía

y la más chiquita pasteles hacía.

4 Haciendo pasteles se quedó dormida

y un sueño soñaba de bien y de alegría:

6 que los pajaritos son sus hermanitos

y las palomitas eran su hermanita.

Repite 6 como si fuera 7 .

Es ésta una versión abreviada de un romance no documentado en la Península y difundido en Oriente, que de allí habrá pasado a Marruecos, según Armistead y Silverman ${ }^{27}$; deriva, al parecer, de una balada griega. En la versión marroquí de Larrea ${ }^{28}$, más cabal que la nuestra, la muchacha le cuenta el sueño a su madre en primera persona; nuestro texto carece, por lo tanto, del núcleo central del romance, constituido por el motivo tradicional del diálogo madre-hija y la interpretación por aquélla del sueño de ésta. No deja de tener interés la presencia de este texto sefardí en la tradición gibraltareña, pues ofrece un claro testimonio de los lazos mantenidos entre las comunidades judías de Gibraltar y Marruecos.

\section{El pretendiente burlado (á-a) (CMP T.5)}

Yo me levantara un lunes y un lunes por la mañana,

2 cogiera mi cantarito, a la fuente iría por agua.

En medio de los caminos con mis amores hallara;

${ }^{26}$ Romancero 43 (págs. 252-253).

27 Véase «A New Collection of Judeo-Spanish Ballads», Journal of the Folklore Institute 3 (1966) págs. 133-153: núm. 7 (págs. 138-139).

${ }^{28}$ Romances 197; otras versiones: MP 129; Mz. RuIz 52. 
4 echóme la mano al cuello, la gargantilla arrancara.

-Tate, tate, caballero, deja el amor pa mañana,

6 lavaré mi lindo cuerpo, mi camisita cambiara.

$4 b$ «la gargantill'arrancara».

Este romance de bodas se conoce únicamente entre los judíos de Marruecos y nuestra versión, bastante abreviada, no ofrece ninguna variante de importancia frente a las otras publicadas ${ }^{29}$; merecerỉa señalarse solamente que frente al mayoritario «tiróme (o tirárame etc.) la mano al pecho», aquí, como en la versión $C$ de Alvar, el pretendiente echa la mano «al cuello» de la esquiva aguadora (v. 4) ${ }^{30}$. El pretexto del baño (v. 6), como han observado Armistead y Silverman en su estudio del romance de Silvana ${ }^{31}$, es un ardid tradicional para evitar o posponer el encuentro con el pretendiente.

14. Santa Irene (á-a,ó) (CMP U.10)

Estando tres niñas bordando corbatas,

2 aguja de oro y dedal de plata, pasó un caballero pidiendo posada.

4 -Si mi madre quiere, yo de buena gana.Le quitan la mesa, le ponen la cama,

6 colchones de hilo, sábanas de holanda. A la medianoche fue y se levantó,

8 de las tres que habían a Elena cogió; la montó a caballo y se la llevó

10 y en medio el camino fue y le preguntó:

-Dime, niña hermosa, ¿cómo tú te llamas?

12 -En mi casa Elena y aquí desgraciada.Cogió un cuchillo y la degolló,

\footnotetext{
29 Alvar Cantos 17.A-D (págs. 242-247); Benoliel 15; Larrea Romances 246; LaRrea Canciones 4.

${ }^{30}$ La consecuencia del manotazo - «la gargantilla arrancara» (4b)- evidencia que en ese mismo sentido ha de entenderse la formulación paralela de BENOLIEL «la gargantilla me cortara" (v. 8), conforme a la acepción "romper, rasgar' de cortar en jaquetía (cfr. Alvar Cantos pág. 244).

${ }^{31}$ Yoná 8 (págs. 267-273): pág. 270 nota 8.
} 
14 hizo un boquete y allí la enterró.

A los pocos meses pasó un pastorcito, 16 una rosa blanca allí encontró.

Repite cada verso con las variantes: $6 b$ «sábana», $15 b$ omite «un».

En un extenso artículo monográfico ha trazado José Pérez Vidal ${ }^{32}$ el origen de este romance, que nació de una leyenda piadosa portuguesa pasada a España y que difundida en la Península, Canarias y América, penetró en Marruecos en fecha reciente. Nuestra versión, sin duda de origen peninsular, difiere en el final de las recogidas por Larrea en Tetuán ${ }^{33}$; incorpora, en cambio, algún detalle análogo a las lecturas de las versiones canarias que cita Pérez Vidal: la transformación de la mártir en una rosa («tumba» o «ermita enramada» en las versiones canarias) tiene al mismo tiempo un valor poético y ejemplar.

\section{Las hijas del merino (polias.)}

-Mamá, ¿quiere usté que vaya y un ratito a la alameda

2 con las hijas de Medina que llevan rica merienda?-

A la hora de merendar se perdió la más pequeña.

4 ¿Dónde la vino a encontrar?: hablando con un galán; ¿el galán qué le decía y el galán qué le decía?

6 -Yo me he de casar contigo o me he de quitar la vida.Mi abuela tiene un peral que le da de perlas finas.

$1 b$ «a l'alameda»; $4 a$ «vin'a 'ncontrar». Se repiten los hemistiquios -salvo los de 5 y $6-$ con la variante $4 a$ «vin' a e.».

Este romance, aunque se conoce entre los judíos de Marruecos, es de origen peninsular moderno. Se canta en los corros infantiles en toda España y en Hispanoamérica, de donde se han publicado muchas versiones ${ }^{34}$, que aparte de ser algo más

\footnotetext{
32 «Santa Irene (Contribución al estudio de un romance tradicional)», Revista de Dialectología y Tradiciones Populares 4 (1949) págs. 518-569.

${ }^{33}$ Romances 235-236. Otra versión: Mz. Ruiz 121.

34 Véase A. Marazuela Albornós, Cancionero segoviano (Segovia 1964) págs. 347-348; F. Rodriguez Marín, Cantos populares españoles, 5 vols. (Sevilla 18821883 ) vol. I pág. 81 (núm. 187); J. VicuÑa Cifuentes, Romances populares y vulgares recogidos de la tradición oral chilena (Santiago de Chile 1912) núm. 80.
} 
extensas, no difieren gran cosa de la nuestra. Ésta es muy parecida a la de Rodríguez Marín, con la omisión de los versos finales de característica ejemplaridad popular: «¿Qué tontas son las mujeres / que de los hombres se fían!» ${ }^{35}$. Estos versos, a su vez, pertenecen a La tórtola del peral (CMP X.23); cuya presencia en nuestra versión, por efecto de la tendencia a abreviar que una vez más podemos advertir, ha quedado reducida a sólo el verso último: «Mi abuela tiene un peral / que le da de perlas finas».

A pesar de que, por el momento, disponemos de sólo quince textos romancísticos de Gibraltar (a los que ha de añadirse el de Zaide reseñado por Menéndez Pidal en MP 19, pero vid. CMP D.5/2) ${ }^{36}$, podemos apuntar tentativamente algunos rasgos de esa tradición aún poco explorada.

Entre los recursos tradicionales de la poesía oral, se advierte como característica constante una tendencia a abreviar, a simplificar los detalles y a eliminar o reducir a lo mínimo el desenlace. Queda por saber si ello es debido a los criterios privativos de nuestra informante o si responde a una característica peculiar de esta subrama de la tradición; pero con nuestra documentación actual nada podemos afirmar con seguridad.

Al igual que la tradición romancística sefardí del norte de Marruecos, la de Gibraltar une textos sefardíes con otros exclusivamente peninsulares. Este fenómeno, que se halla bien ilustrado en nuestro pequeño repertorio, seguramente se evidenciaría aún más si tuviéramos otros ejemplos.

Puede observarse otro rasgo distintivo de la tradición de Gibraltar en relación con la de Marruecos: la escasez de manifestaciones de pronunciación dialectal, debida probablemente

35 Para esta fórmula y otras semejantes véase Armistead y Silverman Yoná págs. 259-262 nota 6 .

36 Además de los romances aquí publicados, mi informante me comunicó los siguientes textos: a) «Señora madama, / si me dais licencia // la retrataría / de pies a cabeza», versión de El retrato de la dama (CMP Y.6); b) «Tus ojos son luceros, / tu cara es luna y sol», canción lírica peninsular moderna; y $c$ ) «Ah immá, ¿cómo lo haré?; / pide por mí, me casaré», copla judeomarroquí de creación moderna, con algunas formulaciones semejantes a las de Mz. Ruiz 11 (vs. 29ss). En encuesta posterior con la misma informante grabé versiones de los romances de Raquel lastimosa (MP 79 / CMP M.7), La calumnia (MP $91 /$ CMP N.5) y Gerineldo (MP $101 / C M P$ Q.1). Véase también S. G. ARMISTEAD, I. M. Hassán y J. H. Silverman, «Four Moroccan Judeo-Spanish Folksong Incipits (1824-1825)», Hispanic Review 42 (1974) págs. 83-87. 
a la ausencia de una judería como entidad social autónoma; frente a ello, el habla arcaica de los judíos de Marruecos, gracias a la vida tradicional de las juderías, estaba expuesta más moderadamente a la influencia del español moderno.

Estas conclusiones provisionales sólo se podrían corroborar y completar mediante la recolección de otros ejemplos de una tradición que todavía queda por explorar **.

\section{ÍNDice de títulos (éstos en cursiva) y primeros versos:}

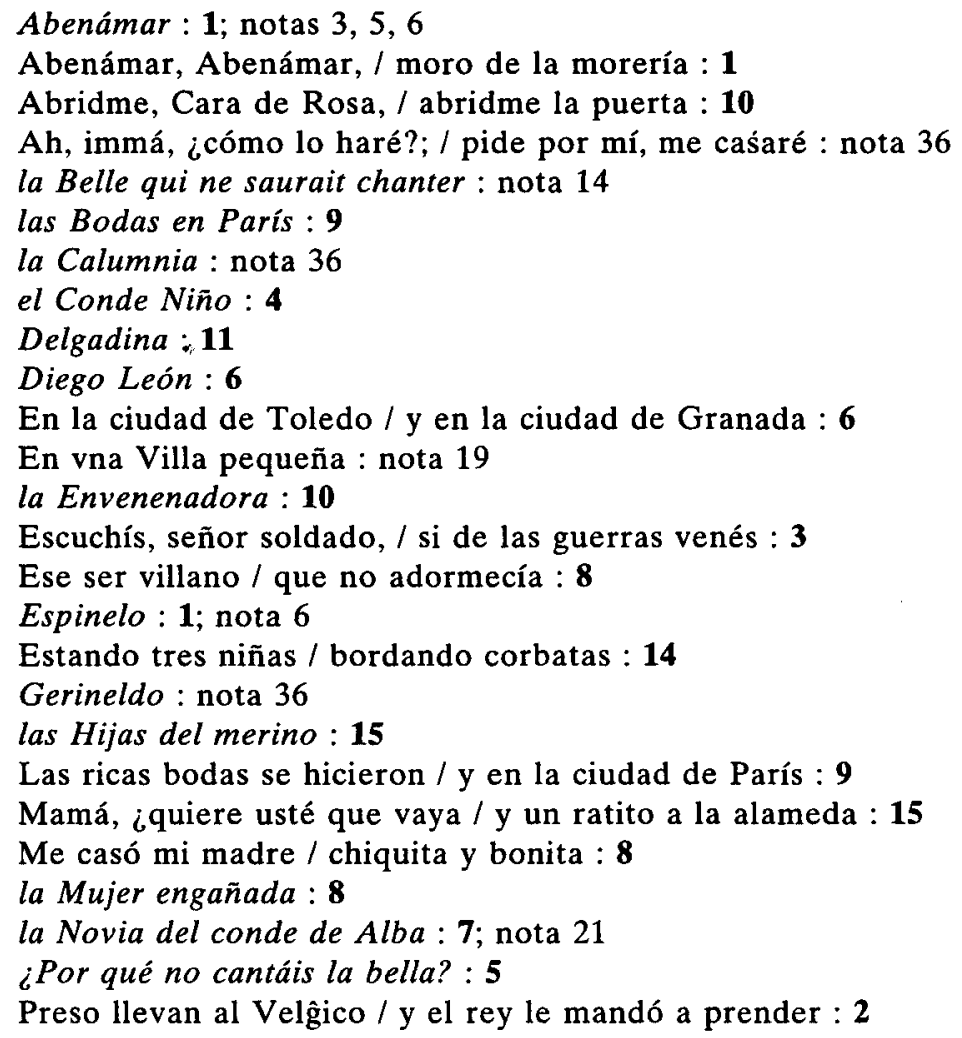

" Quisiera dar las gracias al Prof. Samuel G. Armistead por sus valiosos consejos y correcciones y sus indicaciones bibliográficas, al Dr. Iacob $\mathrm{M}$. Hassán por su cuidada revisión del original, y al Prof. I. J. Katz, que se brindó a hacer la transcripción musical de los textos. Debo especial agradecimiento a la Sra. de Roublev por su amable colaboración, sin la cual no hubiera sido posible este artículo. 
el Pretendiente burlado: $\mathbf{1 3}$

la Princesa y el segador: $\mathbf{5}$

Raquel lastimosa: nota 36

el Retrato de la dama : nota 36

Rey moro tenía tres hijas, / todas tres como la plata : 11

Sancho y Urraca: 2

Santa Irene : 14; nota 32

Se paseaba conde Olivo / mañanita de San Juan : 4

Señora madama / si me dais licencia : nota 36

Silvana : 13

el Sueño de la hija : 12

la Tórtola del peral : 15

Tristes nuevas, tristes nuevas / se decían por Sevilla : 7

Tus ojos son luceros, / tu cara es luna y sol : nota 36

Una hija tiene el re, / una hija regalada : 5

Virgilios : 2

la Vuelta del marido (é) : 2, 3

Y este rey de Francia / tres hijas tenía : 12

Yo me levantara un lunes / y un lunes por la mañana : 13

Zaide : concl.

\section{BiBLIOGRAFÍA CITADA ABREVIADAMENTE}

Alvar, M., «Cinco romances de asunto novelesco recogidos en Tetuán», Estudis Romanics 3 (1951-1952) págs. 57-87.

—, «Los romances de "La bella [en] misa" y de "Virgilios" en Marruecos», Archivum 4 (1954) págs. 264-276.

—, Textos hispánicos dialectales, 2 vols. (Madrid: CSIC, 1960).

- Poesía tradicional de los judios españoles (México: Porrúa, 1966).

- Cantos de boda judeo-españoles (Madrid: CSIC, 1971).

Armistead, S. G., y J. H. Silverman, Judeo-Spanish Ballads from Bosnia (Philadelphia: Univ. of Pennsylvania, 1971).

- The Judeo-Spanish. Ballad Chapbooks of Yacob Abraham Yoná (Berkeley - Los Ángeles: Univ. of California, 1971).

AtTiAs, M., Romancero sefaradí: Romanzas y cantes populares en judeo-español, $2^{\mathrm{a}}$ ed. (Jerusalem: Instituto Ben-Zvi, 1961).

BÉnichou, P., Romancero judeo-español de Marruecos (Madrid: Castalia, 1968).

- Creación poética en el romancero tradicional (Madrid: Gredos, 1968). 
Benoliel, J., "Dialecto judeo-hispano-marroquí o hakitia»: cap. XIII, Boletín de la Real Academia Española 14 (1927) págs. 357-373.

CMP: vid. nota 2.

DURÁN, A., Romancero general o Colección de romances castellanos anteriores al siglo XVIII, 2 vols. (Madrid: Hernando = BAAEE $10 \mathrm{y}$ 16, reimpr. Atlas 1945).

Guastavino Gallent, G., «Cinco romances sefardíes», Africa 8 (1951) págs. 537-539.

Larrea Palacín, A. de, Romances de Tetuán, 2 vols. (Madrid: CSIC, 1952).

_- Canciones rituales hispano-judias (Madrid: CSIC, 1954).

MARtínez Ruiz, J., "Poesía sefardí de carácter tradicional (Alcazarquivir)», Archivum 13 (1963) págs. 79-215.

Martínez Torner, E., Lírica hispánica: Relaciones entre lo popular y lo culto (Madrid: Castalia, 1966).

MENÉndez PIDAl, R., Romancero hispánico (hispano-portugués, americano y sefardi), 2 vols. (Madrid: Espasa-Calpe, 1953).

MP : vid. nota 1.

Ortega, M. L., Los hebreos en Marruecos, $4^{\text {a }}$ ed. (Madrid: Nuestra Raza, 1934).

(Entregado para Estudios Sefardies en 1985)

Adenda (1998): Suplemento bibliográfico, de S. G. Armistead

Celebro tener el privilegio de elaborar este suplemento bibliográfico del importante artículo de nuestra estimada colega Oro AnahoryLibrowicz, quien ahora suma a nuestros conocimientos del romancero judeomarroquí nada menos que toda una nueva subtradición geográfica, la de Gibraltar, la cual hasta la fecha nos había quedado esencialmente desconocida. En lo que sigue me limito en general a publicaciones sobre la tradición sefardí de Marruecos y lo publicado desde 1980 en adelante, pero en ciertos casos no dejo de señalar algún que otro estudio comparativo que ha visto la luz desde esa fecha. Para facilitar la consulta también hago constar las versiones que se recogen en Nahón y en Florilegio (de las que ya da cuenta O. A.-L. en la primera nota del presente artículo). A continuación de cada título (y de la asonancia del romance) cito para la comodidad de los lectores el número apropiado de MP y $C M P$ (separados por /), que ya consta también en las acotaciones de O. A.-L. 
1. Abenámar (10/C5): O. A.-L. publica y estudia esta misma versión en «Bosquejo» pág. 136, y además otros fragmentos de Abenámar, que sirven de prólogo al rarísimo romance de Espinelo, los edita y estudia en "Creación poética" (nota 6 supra). En RSM, Susana WeICH-SHAHAK edita otra versión marroquí de Abenámar, también de procedencia impresa (núm. 86), con su música. En FLSJ VII cap. 22, daremos cuenta de otras varias versiones del romance, todas de origen libresco, al estudiar las diversas manifestaciones de Abenámar en la tradición oral, tanto sefardí comno peninsular. Véase ahora también mi artículo en Estudos de Literatura Oral.

2. Virgilios (é) (46/F8): Nahón 14; RSM 30. Véase la amplia bibliografía en BENARDETE 18, así como el utilísimo estudio monográfico de TrAPERO, quien analiza todos los avatares, antiguos y modernos, de Virgilios en varias subtradiciones hispánicas.

3. La vuelta del marido (é) (59/I2): AROVICH págs. 18-19; BENARDETE 22; Florilegio 10; Nahón 21; RSM 30; SHERR 3.

4. El conde Niño (á) (55/J1): BENARDETE 23B; CSQ 25 y 48; Florilegio 11; Nahón 24; RSM 33. Nótese el estudio monográfico de Catarella.

5. ¿Por qué no cantáis la bella? (é-a) (57/J4): CSQ 14; Florilegio 12A-B; Nahón 25; Ramillete 1; RSM 36.

6. Diego León (á-a) (63/J5): BENARDETE 24; BoAs-NAHón 4; CSQ 26; Florilegio 11; NAHón 26; SÁnchez 29A; Sherr 4; RSM 37; Trapero «Testimonios» 5 . Nótese nuestro breve estudio sobre un antepasado del siglo XVII del romance moderno (En torno págs. 102-104; nota 19 supra).

7. La novia del conde de Alba (i-a) (65/K4): Es la joya de esta colección: un romance rarísimo del que no tenemos, según creo, más noticias marroquíes que las que aporta Menéndez Pidal respecto a una única versión recogida por Benoliel (MP 65; CMP III núm. 26). Para textos portugueses, gallegos y castellanos, todos ellos también muy raros, véase ahora el indispensable índice tipológico de Costa FonTES $(R P I \mathrm{~K} 2)$. O. A.-L. estudia este mismo texto gibraltareño en «Una variante» (nota 21 supra) al compararlo con una versión portuguesa de Trás-os-Montes. Tiene mucha razón al comparar los paralelismos estilísticos de este trágico romance con las características estrategias de las endechas.

8. La mujer engañada (i-a) (74/L13): BOAS-NAHÓN 5; Florilegio 14; Nahón 32A-B; RSM 43-44. Sobre la música del romance, véase KATZ «Stylized Performances». 


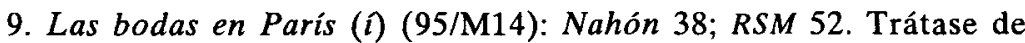
otro romance muy raro en todas las subtradiciones ( $R P I \mathrm{M} 10$ ).

10. La envenenadora (é-a) (88/N2): RSM 52; SÁNCHEZ pág. 93 publica esta misma versión gibraltareña recogida por O. A.-L. El romance es rarísimo y al parecer exclusivamente sefardí (oriental y norteafricano) (CMP N2).

11. Delgadina (á-a) (99/P2): Florilegio 20; Nahón 42; RSM 58. Véanse los estudios de Gutiérrez Esteve.

12. El sueño de la hija (i-a) (129/S6): Florilegio 23; RSM 69; amplia bibliografía: BENARDETE 37 . El relato tiene su origen en una balada griega y habrá llegado a Marruecos por mediación de sefardíes de Oriente (En torno págs. 157-159; nota 27 supra).

13. El pretendiente burlado (á-a) (/T5): BOAS-NAHÓN 11; Nahón 53A-B.

14. Santa Irene (á-a,ó) (/U10): CSQ 34; Florilegio 27; RSM 73; SÁNCHEz págs. 96-97. En este último caso, se publica la misma versión de Flora Ohana recogida por O. A.-L.

15. Las hijas del merino (polias.): No tengo más datos sobre la posible popularidad en Marruecos de esta canción infantil peninsular, pero dada su amplia difusión (nota 34 supra), apenas cabe duda que también la cantarían las niñas sefardíes en Tetuán y las demás comunidades. Ahora conocemos versiones de Canarias (Trapero Gran Canaria núm. 70).

\section{Bibliografía}

ANAhory-Librowicz, Oro, "Creación poética en tres versiones sefardíes del romance de Espinelo», La Corónica 10:1 (1981-1982) págs. 59-64.

_-, "Una variante gibraltareña de La novia del conde de Alba», La Corónica 13:2 (1984-1985) págs. 255-257.

-, «Bosquejo del romancero sefardí», Los sefardíes: Cultura y literatura, ed. Paloma Diaz-Mas (San Sebastián: Univ. del País Vasco, [1987]) págs. 125-141. Armistead, Samuel G., «Para el romance de Abenámar: 'Granada, novia de las ciudades de al-Andalus'», Estudos de Literatura Oral 2 (1996) págs. 10-18.

ARovich dE Bogado, Vilma Haydée, Vestigios de la tradición literaria sefardí en las ciudades de Resistencia y Corrientes (Resistencia, Argentina: Univ. Nacional del Nordeste, [1983?]).

Benardete $=$ Samuel G. Armistead y Joseph H. Silverman, Judeo-Spanish Ballads from New York (collected by Mair José Benardete) (Berkeley Los Angeles - London: Univ. of California Press, 1981).

Boas-Nahón = Samuel G. Armistead, Israel J. Katz y Joseph H. Silverman, «Judeo-Spanish Folk Poetry from Morocco (The Boas-Nahón Collection», 
Yearbook of the International Folk Music Council 11 (1979) págs. 59-75.

Catarella, Theresa L., System and Change: An Approach to the Ballad (tesis de Ph.D., Univ. de California, San Diego, 1979; Dissertation Abstracts International 40:8 [febrero 1980] pág. 4.620A).

CSQ = Oto ANAHORY-Librowicz, Cancionero séphardi du Québec, I (Montreal: Cégep du Vieux Montréal, 1988).

En torno = Samuel G. ARmistead y Joseph H. Silverman, con un estudio etnomusicológico de Israel J. KATZ, En torno al romancero sefardí (Hispanismo y balcanismo de la tradición judeo-española) (Madrid: S.M.P., 1982).

Florilegio = Oro ANAHORY-LiBRowicz, Florilegio de romances sefardíes de la diáspora (Una colección malagueña) (Madrid: C.S.M.P., 1980).

$F L S J=$ Samuel G. Armistead, Joseph H. Silverman e Israel J. Katz, Folk Literature of the Sephardic Jews, 3 vols. (Berkeley - Los Angeles: Univ. of California Press, 1994); vols. IV-VII preparándose para la imprenta.

Gutiérrez Esteve, Manuel, «Sobre el sentido de cuatro romances de incesto», en Homenaje a Julio Caro Baroja, ed. Antonio CARreira et al. (Madrid: Centro de Investigaciones Sociológicas, 1978) págs. 551-579.

-, El incesto en el Romancero popular hispánico: Ensayo de análisis estructural, 3 vols. (tesis Univ. Complutense, Madrid 1981).

KATZ, Israel J., «Stylized Performances of a Judeo-Spanish Traditional Ballad», en Studies in Jewish Folklore, ed. Frank Talmage (Cambridge, Massachusetts: Association for Jewish Studies, 1980) págs. 181-200.

Nahón = Samuel G. Armistead y Joseph H. Silverman, con la colaboración de Oro AnAhory-Librowicz, Romances judeo-españoles de Tánger (recogidos por Zarita Nahón) (Madrid: C.S.M.P., 1977).

Ramillete = Susana WeICH-SHAHAK, Ramillete de romances y coplas sefardies (Jerusalén: Renanot-Instituto de Música Judía, 1991).

$R P I=$ Manuel da Costa Fontes et al., O Romanceiro Português e Brasileiro: Indice Temático e Bibliográfico, 2 vols. (Madison, Wisconsin: Hispanic Seminary of Medieval Studies, 1997).

$R S M=$ Susana Weich-Shahak, con la colaboración de Paloma Díaz MAs, $R o$ mancero sefardí de Marruecos: Antología de tradición oral (Madrid: Alpuerto, 1997).

SÁnCHEZ, Miguel A., Es razón de alabar: Una aproximación a la música tradicional sefardí (Madrid: Comunidad de Madrid, 1997).

ShERR, Daniel, [con transcripciones musicales de Israel J. KATZ], «Seis romances de Barcelona», La Corónica 12:2 (1983-1984) págs. 211-218.

Trapero, Maximiano, El romancero de Gran Canaria, I: Zona del Sureste, transcripciones musicales de Lothar Siemens Hernández (Las Palmas: Mancomunidad de Cabildos, 1982).

- El romance de Virgilios en la tradición canaria e hispánica (La Laguna, Tenerife: El Museo Canario, 1992).

-, «Testimonios del romancero judeo-sefardí en las Islas Canarias», La Corónica 22:1 (1993-1994) págs. 15-23. 


\section{RESUMEN}

Los quince romances aquí incluidos y comentados presentan un rasgo interesante: su origen. Procedentes de una informante sefardí de Gibraltar, constituyen un testimonio único de esta tradición. Aunque los textos son generalmente representativos de la tradición sefardí de Marruecos, dos de ellos son rarísimos (núms. 7 y 10). Esta muestra única no nos permite sacar conclusiones generales sobre la tradición gibraltareña. Sin embargo, se notan ciertos rasgos distintivos: tendencia a la brevedad y a las versiones truncas, incluso en los textos más difundidos, claras influencias de las tradiciones andaluza y marroquí y escasez de pronunciación dialectal sefardí.

\section{SUMMARY}

The fifteen ballads in this article present a special interest: their geographical origin. They were all collected from a Sephardic informant from Gibraltar, and therefore constitute a unique testimony of this tradition. Even though these texts offer a sample of Morocco's most widely known ballads, two of them are a rare find $\left(\mathrm{n}^{\circ} 7\right.$ and 10$)$. It would be premature to draw any general conclusions as to the characteristics of the Sephardic ballads from Gibraltar. However, we may underline some distinctive features of this collection: a tendency for shorter versions, even in the most common and well-known ballads; strong links and similarities with both the Moroccan and Andalusian traditions; and rare cases of dialectal Judeo-Spanish pronunciation. 